Original research article

\title{
Selected aspects of nursing practice related to the usage of evaluation tools for population aged over 60 years
}

\author{
Jitka Doležalová *, Valérie Tóthová, Jan Neugebauer \\ University of South Bohemia in České Budějovice, Faculty of Health and Social Sciences, Institute of Nursing, Midwifery and Emergency Care, \\ České Budějovice, Czech Republic
}

\section{Abstract}

Introduction: The accuracy of evaluation tools is subject to several factors involving nurses. Two of these factors are the level of education and experience. These factors can significantly affect the instrument's objectivity. In terms of providing quality and specific geriatric care, having objective evaluation tools and applying the results are essential.

Objective: The research aimed to determine how nurse education and experience affect the objectivity of evaluation tools. Another aim was to determine how education and experience affected the assessment of selected areas.

Methods: The research was conducted using a quantitative survey involving 501 nurses from the South Bohemian Region. The data was obtained using a non-standardized questionnaire that focused explicitly on the use of evaluation tools.

Results: The results show that nurses with higher levels of education have more experience in using evaluation tools and consider the tools to be useful and effective. The same was confirmed for nurses who have more nursing experience.

Conclusions: Evaluation tools are an essential part of the nursing process, and an emphasis should be placed on learning how to use these tools during nurse training. In the context of geriatric nursing, nurses need special education for the various geriatric specialties. This is also true for the use of geriatric evaluations. In clinical practice, it is necessary to use evaluation tools systematically, logically, and, above all, to implement the results into care plans.
\end{abstract}

Keywords: Evaluation tools; Nursing; Nursing education; Nursing experience; Population over 60

\section{Introduction}

The use of evaluation tools is a routine task in nursing care and is a normal part of the nursing process. Evaluation tools are used to collect information about the patient's physical, psychological, social, and spiritual needs (Jamieson et al., 2019). Regular evaluation of complex needs has the advantage of enabling nurses to monitor the current and future needs of the patient, allowing nursing diagnoses to be made, and helping the nurse prioritize interventions and care (Abdul-Kareem et al., 2019). Knowledge and experience (Elcigil et al., 2011) are considered prerequisites for properly executed nursing assessments. Education plays an important role in the acquisition of knowledge. The level of postgraduate education and the place of clinical practice (Elcigil et al., 2011) are potential barriers to assessing patient needs and problems. Lesa and Dixon (2007) view evaluations as a key part of the nurse's role. For evaluation tools to be used appropriately and objectively, education and experience are essential, as are nurses viewing the evaluation tools as relevant to their nursing practice. It has been shown that nurses with more experience are considered experts in their profession, better at recognizing problems and solutions, better able to integrate these solutions into the nursing process, and work calmly and professionally. The influence of education has also been demonstrated. Nurses with a university degree have wider theoretical and practical skills (Kim et al., 2015). As such, they can better evaluate different situations and are better able to evaluate patient health. However, it is important to think in terms of the education of the whole nursing team, not just individual nurses within it (Kurniawan and Hariyati, 2019).

In the context of nurses using patient evaluations, it is necessary to specify what specific group of patients is involved. If we focus on patients older than 60 years, essentially a geriatric population, it is important to realize that this group may have age-related communication issues (Canêdo et al., 2018). The normal aging process can lead to the need for nursing care, for example, incontinence or poor balance caused by loss of muscle mass (Thiesemann, 2016). Care for those over 60 years can also involve more serious conditions that must be monitored, e.g., geriatric syndromes or polymorbidities affecting multiple organ systems. A comprehensive geriatric assessment (CGA), a multidimensional and multidisciplinary evaluation, was developed by Ellis et al. (2017). The primary areas evaluated for the elderly population with the CGA are functional capacity,

\footnotetext{
* Corresponding author: Jitka Doležalová, University of South Bohemia in České Budějovice, Faculty of Health and Social Sciences, Institute of Nursing, Midwifery and Emergency Care, J. Boreckého 27, 37005 České Budějovice, Czech Republic; e-mail: dolezj08@zsf.jcu.cz; http://doi.org/10.32725/kont.2021.044
} 
self-sufficiency, falls, incontinence, pain, social support, depression, hearing and vision disorders, or the need for permanent nursing care (Spirgiene and Brent, 2018).

\section{Materials and methods}

\section{Study design and research sample}

This descriptive correlation study aimed to determine how the highest educational attainment of nurses and experience affect the ability to use evaluation tools and how it affects evaluations of selected areas.

The selection of respondents was carried out using the random quota selection methodology. The research group consisted of 501 nurses employed in South Bohemian Region hospital facilities, residential facilities, or in-home care. Another criterion for inclusion was that nurses had to provide care to those over 60 years of age. The exclusion criterion was a failure to complete the questionnaire.

\section{Characteristics of the questionnaire}

The non-standardized questionnaire contained 37 questions. It was created based on surveyed topics and an analysis of selected publications. One set of questions focused on experience, place of work, and the highest educational level attained. Another set of questions focused on experience with geriatric populations; this part was based on Bell et al. (2016). The questions focused on the use of evaluation tools in practice, which was based on Armstrong and Mitchell (2008). Questions about selected areas of geriatric care and evaluations of selected geriatric areas were based on Roedl et al. (2016). The questions were "closed". However, for some the option "other" was added. Other questions were constructed using the Likert scale, with options of "maximum, a lot, medium, a little, and not at all". Prior to the research investigation, a pilot study was carried out that assessed comprehensibility. Based on the results of the pilot study, corrections were made to the wording of seven questions. It was primarily about adapting phrases and using appropriate wording to avoid questions that were confusing or misleading. Subsequently, questionnaires were distributed in selected health facilities of the South Bohemian Region.

\section{Data capture}

The research was conducted from March 2019 to January 2020. A total of 510 questionnaires were distributed, and 501 were returned, i.e., a return rate of $98.2 \%$. The returned questionnaires were checked based on previously defined criteria. No questionnaires were excluded based on exclusion criteria. Distribution took place at all health care and residential care facilities and in-home care providers within the South Bohemian Region. The facilities had to meet the condition of providing care to patients over 60 years of age. At hospitals, questionnaires were distributed mainly in the after-care department and the internal ward.

\section{Data analysis}

Data were processed using SASD and SPSS software. The analysis was carried out using the first and second stages of sorting. In the first stage of sorting, frequency tables were constructed for each indicator, and absolute and relative frequencies and mean values were calculated (modus, median, mean, variance, standard deviation, range, variance estimate, and standard deviations, and an interval estimate of mean and variance at 0.05).
In the second sorting stage, pivot tables were constructed with absolute and relative frequencies (column, row, total, and expected) and a sign scheme. As part of the analysis, the chi-square test $-\chi^{2}$ (Pearson Chi-Square) and Independence Test - were used according to the character and number of observations. Furthermore, calculations were made for the Pearson contingency coefficient, the Standard Person coefficient of contingency, the Ćuprov coefficient, the Cramer coefficient, the Wallis coefficient, the Spearman coefficient, and the Correlation Coefficient. The strength of the relationship was measured at three levels of significance: $\alpha=0.05,0.01$, and 0.001 .

As part of the description of the statistically significant relationships analyzed, the values of the chi-square test and the Independence Test are given by default. To determine the direction of a statistically significant relationship between two variables, the level of deviation was calculated for each PivotTable field. In case of an insufficient number of observations, the Yates correction was applied.

\section{Outcomes}

Demographic data results

Of the 501 nurses, 238 (47.5\%) had secondary school education, 128 (25.5\%) reported higher vocational training, and 135 (26.9\%) had university education. Experience was categorized as follows: 18 nurses (3.6\%) reported less than one year of experience working with those over 60 years of age, $123(24.6 \%)$ nurses reported $1-5$ years, 164 (32.7\%) reported 6-10 years, $92(18.4 \%)$ reported $11-15$ years, and 104 (20.8\%) reported 16 years or more (Doležalová, 2021). Representativeness of the sample was based on data from the Institute of Health Information and Statistics of the Czech Republic, more precisely from the document The Network of Health Facilities 2013 (IHIS CR, 2015).

\section{Results}

As part of the study, we monitored and evaluated nurse education and years of nursing experience in relation to completing evaluation tools, evaluation of the over 60 population, the effectiveness of the tools used, and complications observed while assessing the elderly population. Education and years of experience were also observed in connection with the evaluation of selected areas, the list of which was inspired by 12 functional health patterns described by Marjory Gordon, and daily activities that are commonly used in self-sufficiency assessments.

The first area of reference is the relationship with the highest educational level attained and the characteristics of the above-mentioned evaluation tools (Table 1 ).

A statistically significant relationship was demonstrated between a nurse's education and opinions on the usefulness of geriatric patient evaluations. Nurses with higher educations were significantly more likely to consider geriatric patient evaluations to be important; the "medium" score was reported by $47.1 \%(n=236)$ nurses, and "a lot" by $28.3 \%(n=142)$ nurses. A statistically significant relationship between education and opinions on the effectiveness of using evaluation questionnaires was also demonstrated. With more education, nurses considered evaluation questionnaires to be significantly more effective. Effectiveness was monitored as well as usefulness; the most common response was "medium", expressed by $46.1 \%$ of nurses $(n=231)$, and "a little" expressed by $20.0 \%$ of nurses $(n=100)$. A significant relationship was not found involving education and regular use of evaluation tools, or 
Table 1. Relationships between a nurse's education and selected aspects of evaluations

\begin{tabular}{lcccc}
$\begin{array}{l}\text { Highest educational } \\
\text { attainment and association } \\
\text { with evaluations }\end{array}$ & $\begin{array}{c}\text { Value } \\
\chi^{2}\end{array}$ & df & $p$ & $\begin{array}{c}\text { Statistical } \\
\text { significance }\end{array}$ \\
\hline $\begin{array}{l}\text { Completing the evaluation tools } \\
\text { Usefulness of geriatric patient }\end{array}$ & 22.757 & 8 & $<0.01$ & $* *$ \\
$\begin{array}{l}\text { evaluations } \\
\text { Effectiveness of evaluations }\end{array}$ & 22.792 & 10 & $<0.05$ & $*$ \\
$\begin{array}{l}\text { Complications observed in } \\
\text { geriatric patients }\end{array}$ & 16.491 & 20 & 0.686 & n.s. \\
\hline
\end{tabular}

$\chi^{2}$ - chi-square; $p$ - independence test; $\mathrm{df}$ - degrees of freedom; n.s. statistically insignificant difference; ${ }^{*}$ statistically significant difference for significance level $\alpha=0.05)$; ${ }^{* *}$ statistically significant difference for significance level $\alpha=0.01 ;{ }^{* * *}$ statistically significant difference for significance level $\alpha=0.001$.

complications associated with evaluating those 60 years and over.

The second area of interest was the relationship between the highest educational level and the opinion of nurses about evaluating selected geriatric areas - Table 2 (Doležalová, 2021).

A statistically significant relationship was demonstrated between nurse training and all of the characteristics listed in Table 2, except for sexuality. In all cases, significantly greater emphasis was put on monitoring the individual needs of geriatric individuals by nurses with higher levels of education.

Furthermore, the relationship between experience and the regular use of evaluation tools was observed with regard to the usefulness of elderly patient evaluations, the effectiveness of evaluation tools, and complications associated with elderly patients (Table 3).

Table 2. Relationships between a nurse's education with selected areas

\begin{tabular}{|c|c|c|c|c|}
\hline $\begin{array}{l}\text { Highest educational } \\
\text { attainment and association } \\
\text { with selected areas }\end{array}$ & $\begin{array}{c}\text { Value } \\
\chi^{2}\end{array}$ & df & $p$ & $\begin{array}{l}\text { Statistical } \\
\text { significance }\end{array}$ \\
\hline Health & 34.670 & 6 & $<0.001$ & $* * *$ \\
\hline Nutrition & 50.171 & 6 & $<0.001$ & *** \\
\hline Excretion & 15.231 & 6 & $<0.05$ & * \\
\hline Safety (falls) & 55.394 & 6 & $<0.001$ & *** \\
\hline Activity, exercising & 81.833 & 6 & $<0.001$ & *** \\
\hline Sleep, rest & 36.002 & 6 & $<0.001$ & $* * *$ \\
\hline Intellectual abilities & 36.694 & 6 & $<0.001$ & *** \\
\hline Self-concept, self-esteem & 24.220 & 8 & $<0.01$ & ** \\
\hline $\begin{array}{l}\text { Interpersonal relationships } \\
\text { (social contact with loved } \\
\text { ones) }\end{array}$ & 19.084 & 8 & $<0.05$ & $*$ \\
\hline Senses (sight, hearing, etc.) & 29.961 & 8 & $<0.001$ & $* * *$ \\
\hline Sexuality & 11.214 & 6 & 0.082 & n.s. \\
\hline Stress & 18.881 & 8 & $<0.05$ & $*$ \\
\hline Faith & 18.619 & 8 & $<0.05$ & * \\
\hline \multicolumn{5}{|c|}{$\begin{array}{l}\chi^{2} \text { - chi-square; } p \text {-independence test; df - degrees of freedom; n.s. - } \\
\text { statistically insignificant difference; }{ }^{*} \text { statistically significant difference } \\
\text { for significance level } \alpha=0.05) ;{ }^{* *} \text { statistically significant difference for } \\
\text { significance level } \alpha=0.01 ;{ }^{* * *} \text { statistically significant difference for } \\
\text { significance level } \alpha=0.001\end{array}$} \\
\hline
\end{tabular}

Table 3. Relationships between experience and selected aspects of the evaluation

\begin{tabular}{lcccc}
$\begin{array}{l}\text { Experience and relationships } \\
\text { with selected aspects of } \\
\text { evaluation }\end{array}$ & $\begin{array}{c}\text { Value } \\
\chi^{2}\end{array}$ & df & $p$ & $\begin{array}{c}\text { Statistical } \\
\text { significance }\end{array}$ \\
\hline $\begin{array}{l}\text { Completing evaluation tools } \\
47.734\end{array}$ & 16 & $<0.001$ & $* * *$ \\
$\begin{array}{l}\text { Usefulness of geriatric patient } \\
\text { evaluations }\end{array}$ & 30.113 & 16 & $<0.05$ & $*$ \\
$\begin{array}{l}\text { Effectiveness of evaluation } \\
\text { questionnaires }\end{array}$ & 60.849 & 20 & $<0.001$ & $* * *$ \\
$\begin{array}{l}\text { Complications observed in } \\
\text { geriatric patients }\end{array}$ & 26.754 & 40 & 0.946 & n.s. \\
\hline
\end{tabular}

$\chi^{2}$ - chi-square; $p$ - independence test; $\mathrm{df}$ - degrees of freedom; n.s. statistically insignificant difference; ${ }^{*}$ statistically significant difference for significance level $\alpha=0.05$ ); ${ }^{* *}$ statistically significant difference for significance level $\alpha=0.01 ;{ }^{* * *}$ statistically significant difference for significance level $\alpha=0.001$.

A statistically significant relationship was found between nurse experience and the use of evaluation tools. Nurses with more experience used evaluation tools to a significantly greater extent: $39.5 \%$ of nurses $(n=198)$ recorded semi-regular use of evaluations, and $29.9 \%$ of nurses $(n=150)$ reported regular use. A statistically significant relationship between experience and a nurse's opinion on the usefulness of geriatric patient evaluations was also demonstrated. Nurses with more experience were significantly more likely to consider geriatric patient evaluations to be useful. A statistically significant relationship was demonstrated between experience and a nurse's opinion on the effectiveness of evaluation questionnaires. Nurses with more experience, i.e., 11 years or more, were more likely to consider evaluation questionnaires effective.

Experience was also observed in relation to the selected needs of the over 60 population (Table 4).

Table 4. Relationships between experience and daily activities

\begin{tabular}{lcccc}
$\begin{array}{l}\text { Experience and the } \\
\text { relationship with evaluation } \\
\text { of selected areas }\end{array}$ & $\begin{array}{c}\text { Value } \\
\chi^{2}\end{array}$ & df & $p$ & $\begin{array}{c}\text { Statistical } \\
\text { significance }\end{array}$ \\
\hline Health & 33.433 & 12 & $<0.001$ & $* * *$ \\
Nutrition & 32.421 & 12 & $<0.01$ & $* *$ \\
Excretion & 31.456 & 12 & $<0.01$ & $* *$ \\
\hline Safety (falls) & 14.677 & 12 & 0.260 & n.s. \\
Activity, exercising & 24.643 & 12 & $<0.05$ & $*$ \\
\hline Sleep, rest & 16.678 & 12 & 0.162 & n.s. \\
Intellectual abilities & 17.350 & 12 & 0.137 & n.s. \\
Self-concept, self-esteem & 32.613 & 16 & $<0.01$ & $* *$ \\
$\begin{array}{l}\text { Interpersonal relationships } \\
\text { (social contact with loved }\end{array}$ & 29.359 & 16 & $<0.05$ & $*$ \\
ones) & & & & * \\
\hline Senses (sight, hearing, etc.) & 14.444 & 16 & 0.566 & n.s. \\
\hline Sexuality & 22.826 & 12 & $<0.05$ & $*$ \\
\hline Stress & 17.836 & 16 & 0.334 & n.s. \\
Faith & 22.738 & 16 & 0.121 & n.s. \\
\hline & & & & \\
\hline
\end{tabular}

$\chi^{2}$ - chi-square; $p$ - independence test; df - degrees of freedom; n.s. statistically insignificant difference; * statistically significant difference for significance level $\alpha=0.05$ ); ${ }^{* *}$ statistically significant difference for significance level $\alpha=0.01 ;{ }^{* * *}$ statistically significant difference for significance level $\alpha=0.001$. 
A statistically significant relationship was seen between experience and the characteristics listed in Table 4. Except for sexuality, those with more experience placed significantly more emphasis on the need to monitor geriatric patient needs.

Sexuality is more emphasized by nurses with less experience, i.e., 1-5 years, or less than one year of experience.

The range of answers for nurse opinions regarding monitoring specific areas in geriatric patients allowed us to compare mean values, find out which areas nurses consider most important in terms of monitoring, and compare them with each other. This was the first sorting stage, i.e., there was no reduction in variables, and scales were maintained, as stated in the questionnaire. More emphasis was placed on monitoring needs for which the value of modus, median, and mean Table 5 (Doležalová, 2021) was lower. According to nurses, the greatest emphasis was placed on monitoring the general health of the elderly, and the least emphasis was placed on monitoring the sexuality of the elderly.

Table 5. Importance of monitoring the needs of geriatric patients - comparing mean values

\begin{tabular}{|c|c|c|c|c|c|c|}
\hline Level of monitoring of geriatric patients' needs & $N$ & Mo & $\mathrm{Me}$ & Mean & VAR & SD \\
\hline A. Health & 501 & 1 & 2 & 2.040 & 1.004 & 1.002 \\
\hline B. Nutrition & 501 & 3 & 3 & 2.335 & 0.906 & 0.952 \\
\hline C. Excretion & 501 & 3 & 3 & 2.513 & 0.861 & 0.928 \\
\hline D. Safety (falls) & 501 & 3 & 3 & 2.529 & 0.896 & 0.947 \\
\hline E. Activity, exercising & 501 & 3 & 3 & 2.597 & 0.919 & 0.959 \\
\hline F. Sleep, rest & 501 & 3 & 3 & 2.948 & 0.804 & 0.896 \\
\hline G. Intellectual abilities & 501 & 3 & 3 & 2.899 & 0.742 & 0.861 \\
\hline H. Self-concept, self-esteem & 501 & 3 & 3 & 3.228 & 0.894 & 0.946 \\
\hline I. Interpersonal relationships (social contact) & 501 & 3 & 3 & 3.248 & 0.989 & 0.994 \\
\hline J. Senses (sight, hearing, etc.) & 501 & 4 & 3 & 3.263 & 1.312 & 1.145 \\
\hline K. Sexuality & 501 & 4 & 4 & 4.052 & 0.788 & 0.888 \\
\hline L. Stress & 501 & 4 & 4 & 3.577 & 1.194 & 1.093 \\
\hline M. Faith & 501 & 5 & 4 & 3.870 & 1.239 & 1.113 \\
\hline
\end{tabular}

\section{Discussion}

Our results show that nurses with higher education perceive evaluation tools used in the over 60 population as useful and effective. Higher levels of education influenced perceptions of evaluation tools; nurses with higher educations used tools more often in their practice. It was also confirmed that nurses with more education place greater emphasis on assessing selected areas in the older population. Regarding usefulness, effectiveness, and regularity of evaluation, it is also necessary to mention the influence of nursing experience. Our study confirmed the relationship between experience and the evaluation of selected areas in geriatrics, namely nurses with more than 11 years of experience were more likely to find this process important. Taliánová et al. (2013) dealt with a similar topic; according to their research, nurses with more education were more engaged in using evaluation tools than nurses with less education. They also found that experience affects the use of evaluation tools; the greater the experience, the more likely they were to use evaluation tools. The results suggest that nurses who receive a university education or have more than ten years of experience are more comfortable using evaluation tools than nurses with less education or less experience. The results of our study confirm this assumption. In terms of the quality of care provided, one can talk about the role of inexperience, which is also described in connection with the use of evaluation tools by Levett-Jones et al. (2011). According to the authors, inexperience and lack of information lead to poor evaluations of acute conditions, which can put patients in dangerous situations and lead to adverse treatment out- comes. Inexperience can ultimately have a negative effect on the outcome of an evaluation, which, when applied, then leads to inappropriate nursing care. This can be seen as a barrier to working with evaluation tools. Barriers to the use of evaluation tools were also examined by Douglas et al. (2014), who concluded that lack of experience was of particular importance. According to the authors, nurses with ten years or more experience tend to wait less time before performing evaluations, while nurses with less than five years of experience were seen to lack the nursing skills needed to use these tools. Jamshidi et al. (2016) highlighted the role of information with regard to using evaluation tools. The authors reported that if nurses had more knowledge, they were also better at using evaluation tools.

According to the study, the knowledge gained is not related to education, but depends on experience; the authors recommend increasing the amount of clinical training during nursing school. In addition to substantial knowledge and experience, working with evaluation tools requires the ability to choose the appropriate instrument. Falchenberg et al. (2021) say that the basis of a properly conducted evaluation is the ability to understand the individual needs of patients, which is one of the fundamental aspects of professionalism in nursing. Kiljunen et al. (2017) see education as the basis for providing high-quality and professional care in a geriatric environment, leading nurses to acquire complex and advanced competences. Therefore, it is clear from the above sources and from our research that more training in geriatric nursing leads nurses to increased knowledge in this specific area. Morrell et al. (2019) believe that patient evaluations are understudied, and therefore, the skills needed for them are very underdeveloped. In 
geriatric nursing this problem can be solved mainly by specialized education.

\section{Conclusions}

The results of our study highlighted the impact of experience and education of nurses relative to the use and perception of evaluation tools in nursing practice. To provide quality nursing care, it is necessary to combine these two aspects, that is, to motivate nurses to study at university and, from the point of view of geriatric nursing, to deepen their knowledge of aging and age-related changes associated with it. From an educational point of view, it is also necessary to work with evaluation tools in combination with specific aspects of health in an aging population. In the future, the population of seniors will have more and more impact on nursing, mainly due to its increase. As part of taking a patient history and setting goals and interventions, nurses must have expertise in geriatric care and age-related changes, geriatric syndromes, and other issues. This requires using tools modified for those over 60 years. The correct use of evaluation tools and effective use of results affects the quality of care provided and the health status of patients. In terms of the quality of care and the maximum safety of the care provided, the use of a unified set of tools is recommended, as is the tools being updated as needed. In the future, we need to focus on how the results of evaluation tools impact nursing care. It is also recommended that we continue to assess the knowledge and skills of nurses relative to assessment tools for specialized areas of geriatric nursing.

\section{Study limitations}

Our study focused mainly on two important factors, i.e., education and experience. However, the use of evaluation tools depends on several factors, such as understanding the instrument, use of results to modify nursing care, and the composition of the instruments used, which constitute some of the study's limitations. Another limitation was the distribution of the survey only within the South Bohemian Region. Furthermore, a limitation of the study is that individual facilities use different evaluation tools, which can also influence nurses' opinions. Finally, the study uses subjective views of nurses on the issue of evaluation tools.

\section{Ethical statement}

The study was approved by the Ethics Committee of the University of South Bohemia. It was carried out according to the Data Protection Regulations (GDPR) and the Helsinki Declaration (2013). The questionnaire survey was anonymous and voluntary. Study participants were informed about the objectives and relevance of the study and the processing of personal data. At the beginning of the questionnaire, respondents were asked to fill in all questions and follow the GDPR (they did not give their name or workplace).

\section{Conflict of interests}

The authors have no conflict of interests to declare.

\section{Funding}

This project is supported by the Grant Agency of the University of South Bohemia in České Budějovice (project registered as GAJU 058/2018/s).

\title{
Vybrané aspekty ošetřovatelské praxe související s použiváním hodnoticích nástrojů pro populaci starší 60 let
}

\author{
Souhrn \\ Úvod: Správnost používání hodnoticích nástrojů podléhá ze strany sester několika faktorům. Mezi tyto faktory lze zařadit úroveň \\ vzdělání a délku praxe. Uvedené faktory mohou významně ovlivnit to, jak objektivní je použití daných nástrojů. Z hlediska posky- \\ tování kvalitní a specifické geriatrické péče jsou hodnoticí nástroje a aplikace výsledků do péče zcela zásadní. \\ Cíl: Cílem výzkumu bylo zjistit, jaký vliv má vzdělání sester a délka praxe sester na práci s hodnoticími nástroji. Dílčím cílem bylo \\ zjistit, jaký vliv má nejvyšší dosažené vzdělání a délka praxe sester na hodnocení vybraných oblastí. \\ Metodika: Výzkum byl realizován na základě kvantitativního výzkumného šetření, kterého se zúčastnilo 501 sester z Jihočeského \\ kraje. Data byla získána pomocí nestandardizovaného dotazníku a otázky byly zaměřeny konkrétně na práci s hodnoticími ná- \\ stroji. \\ Výsledky: Z výsledků vyplývá, že sestry s vysokoškolským vzděláním více pracují s hodnoticími nástroji, používané nástroje pova- \\ žují za dostačující a za efektivní. To stejné se potvrdilo i u sester, které mají delší dobu praxe. \\ Závěr: Hodnoticí nástroje jsou podstatnou součástí ošetřovatelského procesu a je třeba klást důraz na práci s nástroji již v průbě- \\ hu vzdělávání sester. V rámci geriatrického ošetřovatelství je nutné sestry vzdělávat specificky pro danou oblast, a to i ve sféře \\ geriatrického hodnocení. V klinické praxi je nutné nástroje používat systematicky, logicky a především pracovat i s výsledky, které \\ budou následně přeneseny do plánu péče.
}

Klíčová slova: hodnoticí nástroje; ošetřovatelství; populace starší 60 let; praxe sester; vzdělání sester 


\section{References}

1. Abdul-Kareem K, Lindo JLM, Stennett R (2019). Medicalsurgical nurses' documentation of client teaching and discharge planning at a Jamaican hospital. Intl Nurs Rev 66(2): 191-198. DOI: 10.1111/inr.12487.

2. Armstrong J, Mitchell E (2008). Comprehensive nursing assessment in the care of older people. Nurs Older People. 20(1): 36-40. DOI: 10.7748/nop2008.02.20.1.36.c6346.

3. Bell SP, Vasilevskis EE, Saraf AA, Jacobsen JML, Kripalani S, Mixon, AS, et al. (2016). Geriatric Syndromes in Hospitalized Older Adults Discharged to Skilled Nursing Facilities. J Am Geriatr Soc 64(4): 715-722. DOI: 10.1111/jgs.14035.

4. Canêdo AC, Lopes CS, Lourenço RA (2018). Prevalence of and factors associated with successful aging in Brazilian older adults: Frailty in Brazilian older people Study (FIBRA RJ). Geriatr Gerontol Int 18(8): 1280-1285. DOI: 10.1111/ggi.13334.

5. Doležalová J (2021). Využití měřících a hodnoticích nástrojů pro populaci starší 60 let. In: Tóthová V, Hellerová V (Eds). Využití měřicích nástrojů v ošetřovatelství. Praha: NLN, s.r.o., pp. 78-104.

6. Douglas C, Osborne S, Reid C, Batch M, Hollingdrake O, Gardner G (2014). What factors influence nurses' assessment practices? Development of the Barriers to Nurses' use of Physical Assessment Scale. J Adv Nurs 70(11): 2683-2694. DOI: $10.1111 /$ jan.12408.

7. Elcigil A, Maltepe H, Esrefgil G (2011). Nurses' Perceived Barriers to Assessment and Management of Pain in a University Hospital. J Pediatr Hematol Oncol 33(1): S33-S38. DOI: 10.1097/MPH.0b013e3182121bef.

8. Ellis G, Gardner M, Tsiachristat A, Langhorne P, Burke O, Harwood RH, et al. (2017). Comprehensive geriatric assessment for older adults admitted to hospital. Cochrane Database Syst Rev 9(9): CD006211. DOI: 10.1002/14651858.CD006211.pub3.

9. Falchenberg A, Andresson U, Wireklint Sundstrom B, Bremer A, Andersson H (2021). Clinical practice guidelines for comprehensive patient assessment in emergency care: A quality evaluation study. Nord J Nurs Res 41(4): 207-215. DOI: $10.1177 / 20571585211006980$.

10. IHIS CR (Institute of Health Information and Statistics of the Czech Republic) (2015). Sít zdravotnických zařízení 2013. Praha: UZZIS ČR.

11. Jamieson H, Abey-Nesbit R, Bergler U, Keeling S, Schluter PJ, Scrase R (2019). Evaluating the Influence of Social Factors on
Aged Residential Care Admission in a National Home Care Assessment Database of Older Adults. J Am Med Dir Assoc 20(11): 1419-1424. DOI: 10.1016/j.jamda.2019.02.005.

12. Jamshidi N, Molazem Z, Sharif F, Torabizadeh C, Najafi Kalyani M (2016). The Challenges of Nursing Students in the Clinical Learning Environment: A Qualitative Study. Sci World J 2016: 1846178. DOI: 10.1155/2016/1846178.

13. Kiljunen O, Valimaki T, Kankkunen P, Partanen P (2017). Competence for older people nursing in care and nursing homes: An integrative review. Int J Older People Nurs 12(3): e12146. DOI: 10.1111/opn.12146.

14. Kim K, Han Y, Kwak Y, Kim J (2015). Professional Quality of Life and Clinical Competencies among Korean Nurses. Asian Nurs Res 9(3): 200-206. DOI: 10.1016/j.anr.2015.03.002.

15. Kurniawan MH, Hariyati RTS (2019). Patient assessment responses in nursing practice to enhance patient safety: A systematic review. Enfermería Clínica 29(S2): 459-463. DOI: 10.1016/j.enfcli.2019.04.068.

16. Lesa R, Dixon A (2007). Physical assessment: implications for nurse educators and nursing practice. Int Nurs Rev 54(2): 166-172. DOI: 10.1111/j.1466-7657.2007.00536.x.

17. Levett-Jones T, Gersbach J, Arthur C, Roche J (2011). Implementing a clinical competency assessment model that promotes critical reflection and ensures nursing graduates' readiness for professional practice. Nurse Educ Pract 11(1): 64-69. DOI: 10.1016/j.nepr.2010.07.004.

18. Morrell S, Raplh J, Giannotti N, Dayus D, Dennison S, Bornais J (2019). Physical assessment skills in nursing curricula. JBI Database System Rev Implement Rep 17(6): 1086-1091. DOI: 10.11124/JBISRIR-2017-003981.

19. Roedl KJ, Wilson SL, Fine J (2016). A systematic review and comparison of functional assessments of community-dwelling elderly patients. J Am Assoc Nurse Pract 28(3): 160-169. DOI: $10.1002 / 2327-6924.12273$.

20. Spirgiene L, Brent L (2018). Comprehensive Geriatric Assessment from a Nursing Perspective. In: Hertz K, SantyTomlinson J (Eds). Fragility Fracture Nursing. Perspectives in Nursing Management and Care for Older Adults. Cham: Springer. DOI: 10.1007/978-3-319-76681-2_4.

21. Taliánová M, Jedlinská M, Moravcová M (2013). Využívání hodnotících a měřících škál v ošetřovatelství. Ošetrovatel'stvo: teória, výskum, vzdelávanie 3(1): 25-30.

22. Thiesemann R (2016). Geriatric Medicine at a Glance. Z Gerontol Geriat 49(2): 164-165. DOI: 10.1007/s00391-0151012-y. 